\title{
Follow-up Results of $\mathrm{HCV}$ GT2 Patients After Sofosbuvir/Ribavirin Therapy: Careful Attention to Occurrence of HCC
}

\author{
TOMOHIRO KANEKO ${ }^{1}$, TATSUO KANDA ${ }^{1}$, KAZUSHIGE NIREI $^{1}$, NAOKI MATSUMOTO $^{1}$, \\ MOTOMI YAMAZAKI ${ }^{1}$, TOSHIKATSU SHIBATA ${ }^{1}$, AKINORI TAMURA ${ }^{1}$, MASAHIRO OGAWA ${ }^{1}$, \\ NORIKO NAKAJIMA ${ }^{1}$, SHUNICHI MATSUOKA ${ }^{1}$, KAZUMICHI KURODA $^{1}$, TOMOE KOMORIYA ${ }^{2}$, \\ TATSUO YAMAMOTO ${ }^{3}$, TADATOSHI TAKAYAMA ${ }^{4}$ and MITSUHIKO MORIYAMA ${ }^{1}$ \\ ${ }^{1}$ Division of Gastroenterology and Hepatology, Department of Medicine, \\ Nihon University School of Medicine, Tokyo, Japan; \\ ${ }^{2}$ Department of Sustainable Engineering, College of Industrial Technology, Nihon University, Chiba, Japan; \\ ${ }^{3}$ Department of Obstetrics and Gynecology, Nihon University School of Medicine, Tokyo, Japan; \\ ${ }^{4}$ Department of Digestive Surgery, Nihon University School of Medicine, Tokyo, Japan
}

\begin{abstract}
Background: We examined treatment the efficacy and data on long-term outcomes in real-world Japanese patients infected with hepatitis $C$ virus (HCV) genotype 2 treated with 12-week sofosbuvir/ribavirin combination therapy. Patients and Methods: In a total of 86 patients who were treated with sofosbuvir/ribavirin, sustained virological response (SVR) rates and long-term-outcomes were retrospectively analyzed. Results: The adherence to this combination therapy was $98.8 \%$. The rates of SVR at week 24 (SVR24) achieved with this treatment according to the 'intention-to-treat' and 'per-protocol' analyses were $89.5 \%$ and $96.2 \%$, respectively. Two patients who experienced relapse did not have any previously reported resistance-associated substitutions in the HCV non-structural protein $5 B(N S 5 B)$ polymerase region. We did not observe any patients who experienced late relapse but did observe that $50 \%$ and $1.3 \%$ of patients with and without a previous history of hepatocellular carcinoma (HCC), respectively, developed HCC after achieving SVR24 (with a mean follow-up period of $2.7 \pm 0.8$ years). Conclusion: Patients with SVR should be carefully followed-up to screen for the occurrence of HCC, although it is infrequent.
\end{abstract}

This article is freely accessible online.

Correspondence to: Tatsuo Kanda, MD, Ph.D., Associate Professor, Division of Gastroenterology and Hepatology, Department of Medicine, Nihon University School of Medicine, 30-1 Oyaguchikamicho, Itabashi-ku, Tokyo 173-8610, Japan. Tel: +81 339728111, Fax: +81 339568496, e-mail: kanda.tatsuo@nihon-u.ac.jp

Key Words: HCV, SVR, HCC, late relapse, RAS.
Chronic hepatitis $\mathrm{C}$ virus (HCV) infection is a major cause of hepatocellular carcinoma (HCC) and end-stage liver disease in Japan and Southern Europe $(1,2)$. Recent interferon-free therapy with direct-acting antivirals (DAAs) against $\mathrm{HCV}$ resulted in higher sustained virological response (SVR) rates with shorter treatment durations and few adverse events (3).

In Japan, the estimated proportion of the general population with $H C V$ infection is $1.0-2.0 \%$, and $H C V$ genotype 2 (GT2) accounts for $30 \%$ of chronic $\mathrm{HCV}$ infections (4). The 12-week combination therapy of the HCV non-structural protein 5B (NS5B) inhibitors sofosbuvir and ribavirin was supported by the Japanese health insurance system as the very first DAA therapy for HCV GT2-infected patients $(3,5-7)$. However, the efficacy and follow-up data of this treatment in a group of real-world Japanese patients infected with $H C V$ GT2 are limited and complex (5-7). Although there are different results between phase III clinical trials and real-world data, the 12-week combination therapy of sofosbuvir/ribavirin led to $90-95 \%$ SVR rates in Japanese DAA-naïve patients infected with $H C V$ GT2 (3, 5-7).

Recently, pan-genotypic interferon-free therapies became approved in Japan. The 12-week combination of sofosbuvir/HCV NS5A inhibitor ledipasvir without ribavirin has been available for both HCV GT1 and GT2 infection (8, 9). This combination led to $100 \%$ and $96 \%$ SVR rates in patients infected with $H C V$ GT1 and GT2, respectively $(8,9)$.

The 8-week combination of the $H C V$ NS3 inhibitor glecaprevir/HCV NS5A inhibitor pibrentasvir without ribavirin has also been available for patients without cirrhosis infected with both HCV GT1 and GT2 (10). This combination led to $99.2 \%$ and $98.2 \%$ SVR rates in patients infected with $H C V$ GT1 and GT2, respectively (10). Thus, 
interestingly, the SVR rates of patients with $H C V$ GT2 infection may be inferior to those of patients with $H C V$ GT1 infection who receive DAA therapy.

It is possible that the results after achieving SVR with interferon-free therapy may be different from those after achieving SVR with interferon-containing treatment because the population is aging in Japan (6) and rapid immunological changes are also observed (11). Unexpectedly high rates of early tumor recurrence and occurrence have been reported in patients with $\mathrm{HCV}$-related $\mathrm{HCC}$ undergoing interferon-free therapy $(12,13)$, although they are a controversial (14). Late relapse of $H C V$ RNA has also been reported $(15,16)$.

These findings prompted us to analyze resistanceassociated substitutions (RASs) in $H C V$ GT2 patients with treatment failure and the data on long-term outcomes in $\mathrm{HCV}$ GT2-infected patients treated with the 12-week combination therapy of sofosbuvir/ribavirin. In particular, we followed up patients who achieved SVR at week 24 (SVR24). We focused on the virological response and the occurrence of $\mathrm{HCC}$ in real-world Japanese $H C V$-GT2-positive patients who were treated with sofosbuvir/ribavirin.

\section{Patients and Methods}

Patients. Patients were retrospectively enrolled at Nihon University School of Medicine Itabashi Hospital, Tokyo, Japan. Patients were eligible if they met the following criteria: i) Chronically infected with $H C V$ GT2; ii) age more than 20 years; iii) negative for the HBs antigen; iv) negative for human immunodeficiency virus; v) no severe anemia; vi) no severe renal diseases; vii) no severe heart diseases; viii) no severe mental diseases; ix) no current intravenous drug abuse ; $x$ ) no pregnancy ; xi) no previous exposure to DAAs ; xii) no Child-Pugh B or C cirrhosis (class A acceptable) ; xiii) no current $\mathrm{HCC}$; and xiv) the initiation of combination therapy with sofosbuvir/ribavirin between 2013 and 2017.

Study design. Data for Japanese HCV GT2-infected patients who were previously treated with a 12-week combination of sofosbuvir/ribavirin were analyzed. We included 86 consecutive patients in the present study (Figure 1). Participation in the present study has been posted at our institutions. Written informed consent was obtained from the patients for the analysis of HCV RASS. This study was approved by the Nihon University School of Medicine Itabashi Hospital Institutional Review Board (RK-161213-7 and RK-181009-4) and conformed to the ethical guidelines of the Declaration of Helsinki. In the present study, $400 \mathrm{mg}$ of sofosbuvir per day plus a weight-based amount of ribavirin (400$1,000 \mathrm{mg}$ ) per day were perorally administered for 12 weeks (3). Clinical and laboratory assessments were performed at least every 4 weeks before and during treatment, and every 24 weeks after the end of treatment (EOT). Adverse events (17) were noted in patient interview, physical examinations and laboratory tests.

Serum biochemical tests and hematological tests. Serum liver function tests, determination of the estimated glomerular filtration rate (eGFR) and hematological tests were performed according to standard methods at least every 4 weeks before and during treatment and every 24 weeks after EOT.
Diagnosis of HCC and liver cirrhosis. Patients were subsequently followed-up through an HCC surveillance program based on tumor markers with or without ultrasonography evaluations every 4-6 months. An intrahepatic nodule was considered to be HCC on contrast-enhanced computed tomography (CT) or gadoliniumethoxybenzyl-diethylenetriamine penta-acetic acid magnetic resonance imaging when both a hypervascular nodule in the arterial phase and a hypovascular nodule in the late phase were demonstrated. Cirrhosis was diagnosed by ultrasonography (sign of cirrhosis) with or without transient elastography [Fibroscan (Echosens, Paris, France) liver stiffness more than $12 \mathrm{kPa}$ ] (5).

Determination of HCV RNA and HCV GTs. Serum HCV RNA levels were determined using the COBAS 6800/8800 system (Roche Diagnostics K.K., Minato-ku, Tokyo, Japan) with detection limits of $\sim 40 \mathrm{IU} / \mathrm{ml}$. HCV GTs were determined by previously described methods (18).

Assessment of treatment efficacy. SVR12, SVR24 and SVR48 were defined as undetectable serum $H C V$ RNA at 12, 24 and 48 weeks after EOT, respectively (19). Relapse was defined as undetectable $H C V$ RNA at EOT followed by the reappearance of $H C V$ RNA (5).

Determination of RASs. Serum was obtained from the two patients who experienced relapse (patients 1 and 2) and stored at $-80^{\circ} \mathrm{C}$ until analysis. Two sets of amplification primers were generated for $\mathrm{HCV}$ $\mathrm{NS} 4 \mathrm{~B}, \mathrm{NS} 5 \mathrm{~B}$ and the 3'-nontranslated region of $\mathrm{HCV}$ GT2 based on the sequences previously reported (20-23).

Nucleic acids were extracted from $140 \mu \mathrm{l}$ of serum using the QIAamp Viral RNA Mini kit (Qiagen, Tokyo, Japan) according to the manufacturer's instructions. cDNA was synthesized using random primers and Super-Script III Reverse Transcriptase (Invitrogen, Carlsbad, CA, USA). Firstly, polymerase chain reaction (PCR) was performed using KOD-Plus-Neo (Toyobo, Osaka, Japan) with 5'-CTGGAGCCTGAGCAGGTAGAGC-3' and 5'-GGGAGTAGGAA AAGGCCTACCC-3' under the following conditions: $2 \mathrm{~min}$ denaturation at $94^{\circ} \mathrm{C}, 35$ cycles at $98^{\circ} \mathrm{C}$ for $10 \mathrm{~s}$ and $68^{\circ} \mathrm{C}$ for $80 \mathrm{~s}$, and 5 min extension at $68^{\circ} \mathrm{C}$ on the GeneAmp PCR system 9700 (Applied Biosystems, Foster, CA, USA). A nested PCR was performed using KOD-Plus-Neo (Toyobo) with 5'-CTCCGT CGTGTGCTGCTCCATG3' and 5'-AGTTTGAG CTTGGTC TTCACCG-3' under the same PCR conditions described above. PCR products were cloned into Zero Blunt TOPO (Thermo Fisher Scientific, Waltham, MA, USA) and directly sequenced. Nucleotide sequences in the present study were compared with those of $H C V$ GT1a H77 (GenBank accession no. AF009606) (20), $H C V$ GT1b Con1 (GenBank accession no. AJ238799) (21), HCV GT2a JFH1 (GenBank accession no. AB047639) (22) and HCV GT2b HC-J8 (GenBank accession no. D10988) (23). Nucleotide sequences were analyzed with GENETYX 10 (GENETYX Corp., Tokyo, Japan). All nucleotide sequences from the present study have been deposited in the DNA Data Bank of Japan (https://www.ddbj.nig.ac.jp/indexe.html)under accession number LC480953 - LC480956.

Statistical analysis. Data are expressed as the means \pm standard deviations (SDs). Statistical analyses of patient characteristic were performed by univariate analysis with the Student's $t$-test or the chisquared test. Values of $p<0.05$ was considered statistically significant. Statistical analysis was performed with DA Stats software version PAF01644 (NIFTY Corp., Tokyo, Japan) and Excel Statistics program for Windows 2010 (SSRI, Tokyo, Japan). 


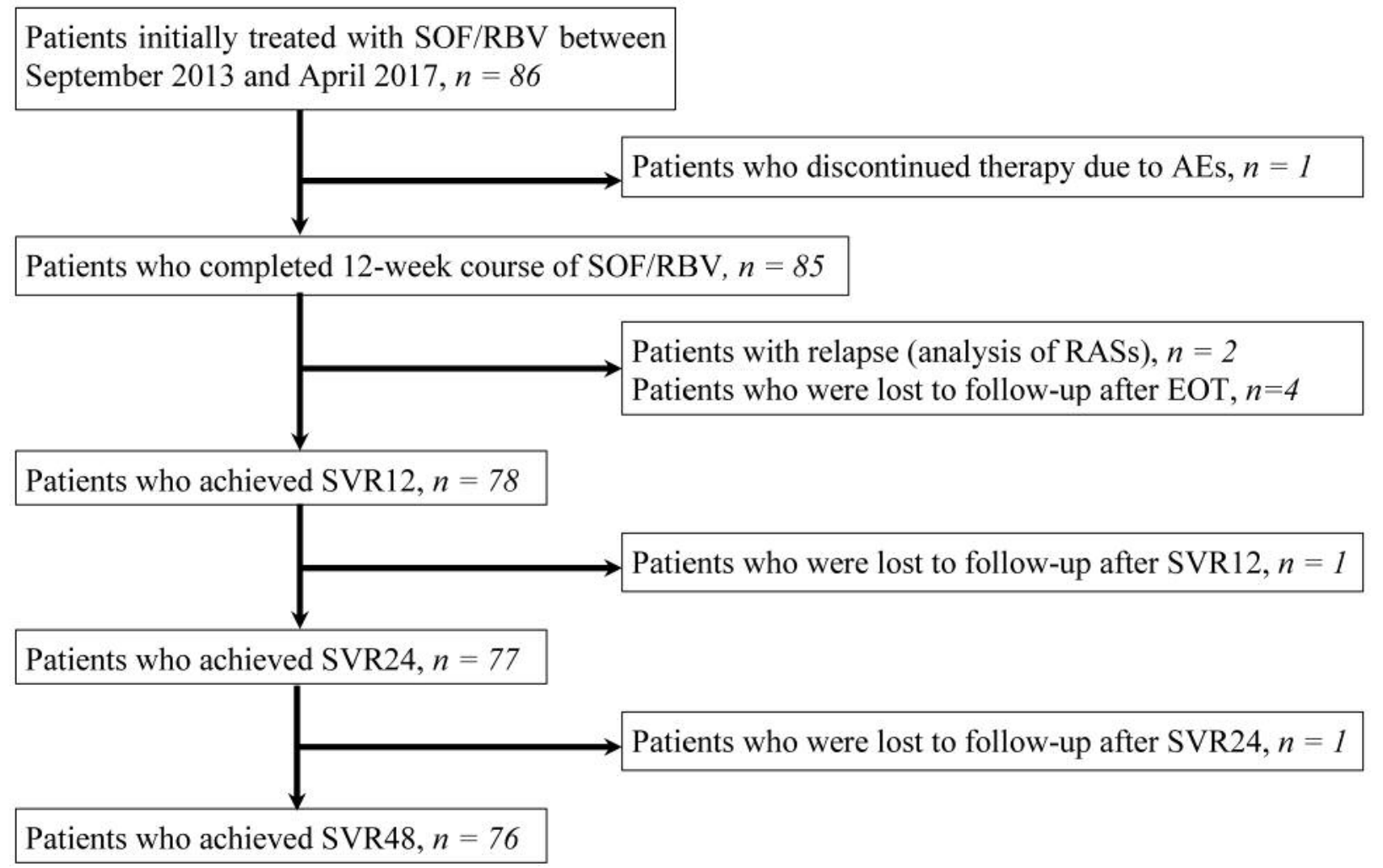

Figure 1. Flowchart showing the patients who were enrolled in this study. SOF: Sofosbuvir; RBV: ribavirin; AEs: adverse events; EOT: end of treatment; SVR: sustained virological response: RASs: Resistance-associated substitutions.

\section{Results}

Patient characteristics. The characteristics of the 86 patients in the present study are shown in Table I. The mean age of patients in the present study was older than that of the patients in the Japanese phase III study (57 years) (3). In total, 10.4\% of patients were interferon-experienced. The mean liver stiffness was $8.9 \pm 7.0 \mathrm{kPa}$, and $22 \%$ of the patients had cirrhosis. Concerning the prevalence of $H C V$ GTs, $H C V$ GT2a was the predominant subtype in the present study.

Notably, two patients with a previous history of $\mathrm{HCC}$ were also included: A 69-year-old man infected with $\mathrm{HCV}$ GT2b who had undergone radical surgery for HCC 5 months before the initiation of DAA therapy, and a 64-year-old man infected with $H C V$ GT2b who had undergone radical surgery for HCC 4.5 years and 1.5 years before the initiation of DAA therapy.

Adherence to the combination therapy of sofosbuvir/ribavirin. In total, 86 Japanese patients underwent treatment with combination therapy with sofosbuvir/ribavirin (Figure 1). Only one patient discontinued taking this combination due to an elevated serum creatinine level $(1.45 \mathrm{mg} / \mathrm{dl})$ (Table II). In this patient, $H C V$ RNA was undetectable at week 4, but $H C V$ RNA reappeared after the cessation of therapy. This patient has been followed-up for 2.5 years, during which time he has not receive antiviral treatment, but HCC has not yet developed. It is noteworthy that 85 patients $(98.8 \%)$ completed the 12 -week course of sofosbuvir/ribavirin, meaning that adherence to this combination therapy was superior to that of interferonincluding treatment (24). No other serious adverse events were observed.

Efficacy of the combination therapy of sofosbuvir/ribavirin. The SVR12 rates according to the 'intention-to-treat' and 'per-protocol' analyses were 90.6\% (78/86) and 96.2\% (78/81), respectively. The SVR24 rates according to the 'intention-to- treat' and 'per-protocol' analyses were $89.5 \%$ (77/86) and 96.2\% (77/80), respectively. The SVR48 rates according to the 'intention-to-treat' and 'per-protocol' analyses were $88.3 \%$ (76/86) and $96.2 \%$ (76/79), respectively (Figure 1). Of the nine interferon-experienced patients, eight, seven and seven patients achieved SVR12, SVR24 and SVR48, respectively, and one experienced relapse. Thus, the efficacy of sofosbuvir/ribavirin combination therapy appears to be excellent at least 48 weeks after EOT. 
Analysis of RASs. Two patients experienced relapse after the EOT with the 12-week sofosbuvir/ribavirin combination therapy (Table II), and these two both had infections with $H C V$ GT2b. We sequenced the $H C V$ NS5B polymerase regions in post-treatment sera collected from these two patients by Sanger methods and compared them with previously reported RASs (25). We did not identify any sofosbuvir-related RASs at positions L159, S282, C316, L320 and V321 (Table III). Among previously reported RASs, M414Q, a RAS related to HCV NS5B inhibitor dasabuvir and $H C V$ GT1, was identified in both patients with relapse, and A421V, aa RAS related to $H C V$ NS5B inhibitor beclabuvir and $H C V$ GT1a, was identified in both patients with relapse; however, these RASs were also found in $\mathrm{HCV}$ GT2a JFH1 and GT2b HCJ8, which were from DAAtreatment naïve patients. Fortunately, the two patients with relapse in the present study achieved SVR after retreatment with a 12-week course of glecaprevir/pibrentasvir combination therapy.

Virological response after EOT in patients with SVR24. In the present study, 77 patients achieved SVR24 (Figure 1). It has been reported that late relapse can occur in HCV RNApositive patients with SVR after interferon-including and interferon-free therapies against HCV infection (16). Although we followed-up these patients with SVR24 for a mean of $2.7 \pm 0.8$ years, we did not observe any with $\mathrm{HCV}$ RNA relapse or HCV reinfection among the HCV GT2infected patients who achieved SVR24 after the 12-week combination therapy with sofosbuvir/ribavirin (Table IV).

Occurrence of HCC after EOT in patients with SVR24. We did not observe any patients in whom HCC occurred during therapy with the combination of sofosbuvir/ribavirin or during the 24 weeks after therapy. After SVR24 was achieved, two patients developed HCC $(2.5 \%, 2 / 77)$ (Table $\mathrm{V})$. Among patients with and without a previous history of HCC, $50 \%(1 / 2)$ and $1.3 \%(1 / 75)$, respectively, developed HCC after SVR24.

We also compared the characteristics of patients who did and did not develop HCC (Table VI). Univariate analysis demonstrated that patients with the HCC occurrence after SVR tended to be male and had a lower platelet count, a history of HCC and longer follow-up period. Multivariate logistic regression analysis of factors among those investigated failed to demonstrate that any associated with the development of HCC because the number of patients was too small.

Among the three patients who experienced reappearance of $H C V$ RNA, only one patient developed HCC. In this patient, HCC developed while HCV RNA was undetectable after the 12-week retreatment with glecaprevir/pibrentasvir (Table II, patient 1).
Table I. Clinical characteristics at the baseline of the 'intention-to-treat' patients.

\begin{tabular}{lc}
\hline Characteristic & All patients $(\mathrm{n}=86)$ \\
\hline Male/female, $\mathrm{n}$ & $40 / 46$ \\
Mean age $\pm \mathrm{SD}$, years & $60.5 \pm 11.1$ \\
Mean BMI $\pm \mathrm{SD}, \mathrm{kg} / \mathrm{m}^{2}$ & $23.2 \pm 3.8$ \\
Mean $H C V \mathrm{RNA} \pm \mathrm{SD}, \mathrm{IU} / \mathrm{ml}$ & $2,430,000 \pm 3,324,000$ \\
Genotype: $2 \mathrm{a} / 2 \mathrm{~b} / \mathrm{unknown}, \mathrm{n}$ & $53 / 32 / 1$ \\
Interferon-naïve/-experienced, $\mathrm{n}$ & $77 / 9$ \\
Chronic hepatitis/cirrhosis, $\mathrm{n}$ & $67 / 19$ \\
Mean AST $\pm \mathrm{SD}, \mathrm{IU} / \mathrm{l}$ & $52.7 \pm 41.8$ \\
Mean ALT $\pm \mathrm{SD}, \mathrm{IU} / \mathrm{l}$ & $55.9 \pm 53.8$ \\
Mean hemoglobin $\pm \mathrm{SD}, \mathrm{g} / \mathrm{dl}$ & $13.6 \pm 1.7$ \\
Mean platelet count $\pm \mathrm{SD}, 10^{3} / \mu \mathrm{l}$ & $182 \pm 67$ \\
Mean eGFR $\pm \mathrm{SD}, \mathrm{ml} / \mathrm{min} / 1.73 \mathrm{~m}{ }^{2}$ & $76.8 \pm 15.4$ \\
History of $\mathrm{HCC}:$ Yes/no, $\mathrm{n}$ & $84 / 2$ \\
History of diabetes mellitus: $\mathrm{Yes} / \mathrm{no}, \mathrm{n}$ & $72 / 14$ \\
\hline
\end{tabular}

BMI: Body mass index; $H C V$ : hepatitis C virus; AST: aspartate aminotransferase; ALT: alanine aminotransferase; eGFR: estimated glomerular filtration rate; HCC: hepatocellular carcinoma; SD: standard deviation.

\section{Discussion}

Although the current interferon-free combination therapies for HCV GT2-infected patients with chronic hepatitis and cirrhosis result in higher SVR rates, SVR rates in Japanese patients infected with $H C V$ GT2 need to be more improved further (8-10). This retrospective study also demonstrated that the SVR rates and adherence to the 12-week combination of sofosbuvir plus weight-based ribavirin were better than those for the interferon-containing regimens (24), supporting the results of previous studies $(3,5-7)$.

Sofosbuvir/ribavirin treatment was associated with few serious adverse events; discontinuation of therapy due to serum creatinine elevation was observed in one patient $(1.1 \%)$. Before the initiation of this combination therapy, his eGFR was $75.7 \mathrm{ml} / \mathrm{min} / 1.73 \mathrm{~m}^{2}$. Saxena et al. reported that patients with eGFRs $\leq 45 \mathrm{ml} / \mathrm{min} / 1.73 \mathrm{~m}^{2}$ more frequently had anemia, worse renal function and more serious adverse events than their counterparts when taking sofosbuvircontaining regimens (26). During combination therapy with sofosbuvir/ ribavirin, close monitoring of renal function is also required.

The clinical impact of DAA RASs in the HCV NS5B region on sofosbuvir/ribavirin treatment failure is still unclear $(5-7,25)$. The two patients who experienced relapse had cirrhosis, which is also one of the risk factors for $\mathrm{HCV}$ RNA reappearance (6), and did not have any RASs in the $H C V$ NS5B polymerase region, which had been previously reported (25). As in HCV NS5B, 1,256 base pairs need to be covered to include all clinically relevant DAA RASs; it may 
Table II. Baseline data on patients who experienced hepatitis C virus (HCV) relapse after combination therapy with sofosbuvir and ribavirin.

\begin{tabular}{|c|c|c|c|c|c|c|c|c|c|c|c|}
\hline Patient & $\begin{array}{l}\text { Age (years)/ } \\
\text { gender }\end{array}$ & $\begin{array}{l}\mathrm{HCV} \\
\mathrm{GT}\end{array}$ & $\begin{array}{c}H C V \text { RNA } \\
(\mathrm{IU} / \mathrm{ml})\end{array}$ & $\begin{array}{l}\text { Previous } \\
\text { treatment }\end{array}$ & $\begin{array}{c}\text { BMI } \\
\left(\mathrm{kg} / \mathrm{m}^{2}\right)\end{array}$ & $\begin{array}{l}\text { Liver stiffness } \\
(\mathrm{kPa}) / \text { cirrhosis }\end{array}$ & $\begin{array}{l}\text { AST } \\
(\mathrm{IU} / 1)\end{array}$ & $\begin{array}{l}\text { ALT } \\
(\mathrm{IU} / \mathrm{l})\end{array}$ & $\begin{array}{l}\text { Hemoglobin } \\
\qquad(\mathrm{g} / \mathrm{dl})\end{array}$ & $\begin{array}{l}\text { Platelet count } \\
\left(10^{3} / \mu \mathrm{l}\right)\end{array}$ & $\begin{array}{c}\mathrm{eGFR}(\mathrm{ml} / \mathrm{min} / \\
\left.1.73 \mathrm{~m}^{2}\right)\end{array}$ \\
\hline $1 *$ & 55/Male & $2 b$ & 630,000 & None & 25.4 & 25.3/Yes & 231 & 218 & 15.7 & 62 & 75.7 \\
\hline $2 * *$ & 58/Male & $2 b$ & $3,162,000$ & IFN & NA & 32/Yes & 86 & 94 & 16 & 200 & 81.7 \\
\hline $3^{\#}$ & 54/Male & $2 b$ & $12,589,000$ & None & 19.9 & $9.2 / \mathrm{No}$ & 93 & 91 & 14.7 & 136 & 75.7 \\
\hline
\end{tabular}

BMI: Body mass index; AST: aspartate aminotransferase; ALT: alanine aminotransferase; eGFR: estimated glomerular filtration rate; HCC: hepatocellular carcinoma; IFN: interferon; NA: not available. None of these patients had a history of HCC or diabetes mellitus. HCV RNA: *Relapse 8 weeks after the end of treatment; **relapse at 4 weeks after the end of treatment; \#undetectable at week 4 , but therapy was discontinued on day 45 due to the elevation of serum creatinine level $(1.45 \mathrm{mg} / \mathrm{dl})$, with subsequent relapse.

Table III. Resistance associated substitutions in patients with hepatitis $C$ virus (HCV) GT2b infection who experienced relapse after combination therapy with sofosbuvir/ribavirin in the present study.

\begin{tabular}{|c|c|c|c|c|c|c|c|c|c|c|c|c|c|}
\hline \multirow[b]{2}{*}{ AA position } & \multicolumn{13}{|c|}{ Substitution } \\
\hline & L159 & S282 & M289 & C316 & L320 & V321 & S368 & N411 & M414 & A 421 & E446 & Y448 & P495 \\
\hline GT1a (H77) & - & - & $\mathrm{C}$ & - & - & - & - & - & - & - & - & - & A \\
\hline GT1b (Con1) & - & - & $\mathrm{C}$ & - & - & - & - & - & - & - & $\mathrm{Q}$ & - & - \\
\hline GT2a (JFH-1) & - & - & - & - & - & - & - & - & $\mathrm{Q}$ & $\mathrm{V}$ & - & - & $\mathrm{N}$ \\
\hline GT2b (HC-J8) & - & - & - & - & - & - & - & - & $\mathrm{Q}$ & V & - & - & - \\
\hline GT2b Patient 1 & - & - & - & - & - & - & - & - & $\mathrm{Q}$ & V & - & - & - \\
\hline GT2b Patient 2 & - & - & - & - & - & - & - & - & $\mathrm{Q}$ & V & - & - & - \\
\hline
\end{tabular}

AA: Amino acid; -, no substitution compared to AA in the top line. H77 (AF009606) (20); Con1 (AJ238799) (21); JFH1 (AB047639) (22); HC-J8 (D10988) (23).

be more difficult to determine the RASs in $H C V$ NS5B regions than in $H C V$ NS3 or NS5A (20). Further studies will be needed regarding sofosbuvir-related RASs.

Hayashi et al. reported that late reappearance of the original $H C V$ strain was confirmed by direct sequencing in $0.96 \%(4 / 413)$ of patients with SVR after treatment with the $H C V \mathrm{NS} 3 / 4 \mathrm{~A}$ inhibitor asunaprevir and the $H C V$ NS5A inhibitor daclatasvir, and patients redeveloped serum $H C V$ RNA at 6, 12, 12 and 26 months after achieving SVR24 (16). In the present study, no patient who achieved SVR24 after treatment with sofosbuvir/ribavirin redeveloped $H C V$ RNA. Pisaturo et al. reported that $5.4 \%$ of patients with DAArelated SVR12 experienced late relapse (after the achievement of a SVR12; median=24 weeks, range $=24-72$ weeks) (27). Although late relapse is infrequent, posttreatment follow-up is very important in the DAA era, as it was in the interferon era $(28,29)$. When liver function is worse after the achievement of SVR, $H C V$ RNA should be examined to rule out late relapse.

Although it is likely that exposure to DAAs was associated with a decrease in all-cause mortality and HCC (30), we observed that $3.4 \%(3 / 86)$ of the patients who received sofosbuvir/ribavirin, including two who achieved SVR24, developed HCC, suggesting that careful follow-up
Table IV. Virological response after the end of treatment (EOT) in patients with sustained virological response at week 24 ( $n=77)$.

\begin{tabular}{lcc}
\hline $\begin{array}{l}\text { Time after } \\
\text { EOT (years) }\end{array}$ & $\begin{array}{c}\text { Total patients, } \\
\mathrm{n}\end{array}$ & $\begin{array}{c}\text { Patients with undetectable } \\
H C V \text { RNA, n }(\%)\end{array}$ \\
\hline 1 & 76 & $76(100)$ \\
1.5 & 71 & $71(100)$ \\
2 & 70 & $70(100)$ \\
2.5 & 63 & $63(100)$ \\
3 & 45 & $45(100)$ \\
3.5 & 16 & $16(100)$ \\
4 & 6 & $6(100)$ \\
4.5 & 1 & $1(100)$ \\
5 & 1 & $1(100)$ \\
\hline
\end{tabular}

$H C V$ : Hepatitis $\mathrm{C}$ virus.

of patients after DAA therapy is needed. After SVR was achieved with sofosbuvir/ribavirin treatment, HCC occurred in one out of two patients or $1.3 \%(1 / 75)$ of patients with and without a history of $\mathrm{HCC}$, respectively. Together, these findings indicate that careful attention should be paid to patients with a history of HCC after they achieve SVR. 
Table V. Patients in whom hepatocellular carcinoma (HCC) occurred after sustained virological response was achieved.

\begin{tabular}{|c|c|c|c|c|c|c|c|c|c|c|c|c|}
\hline Patient & $\begin{array}{c}\text { Age } \\
\text { (years)/ } \\
\text { gender }\end{array}$ & $\begin{array}{c}\mathrm{HCV} \\
\mathrm{GT}\end{array}$ & $\begin{array}{c}H C V \\
\text { RNA } \\
(\mathrm{IU} / \mathrm{ml})\end{array}$ & $\begin{array}{l}\text { Previous } \\
\text { treatment }\end{array}$ & $\begin{array}{c}\text { BMI } \\
\left(\mathrm{kg} / \mathrm{m}^{2}\right)\end{array}$ & $\begin{array}{c}\text { Liver } \\
\text { stiffness } \\
(\mathrm{kPa}) / \text { cirrhosis }\end{array}$ & $\begin{array}{l}\text { AST } \\
(\mathrm{IU} / \mathrm{l})\end{array}$ & $\begin{array}{l}\text { ALT } \\
(\mathrm{IU} / 1)\end{array}$ & $\begin{array}{c}\text { Hemoglobin } \\
(\mathrm{g} / \mathrm{dl})\end{array}$ & $\begin{array}{l}\text { Platelet count } \\
\left(10^{3} / \mu \mathrm{l}\right)\end{array}$ & $\begin{array}{c}\text { eGFR } \\
(\mathrm{ml} / \mathrm{min} / \\
\left.1.73 \mathrm{~m}^{2}\right)\end{array}$ & $\begin{array}{l}\text { History } \\
\text { of HCC }\end{array}$ \\
\hline $4^{*}$ & 64/Male & $2 b$ & $5,011,000$ & Naïve & 24.7 & NA/Yes & 50 & 66 & 15.4 & 153 & 76.8 & Yes \\
\hline $5^{* *}$ & 65/Male & $2 a$ & 316,000 & Naïve & 20.2 & NA/Yes & 49 & 36 & 11.3 & 207 & 79 & No \\
\hline
\end{tabular}

BMI: Body mass index; AST: aspartate aminotransferase; ALT: alanine aminotransferase; eGFR: estimated glomerular filtration rate; HCC: hepatocellular carcinoma; IFN: interferon; NA: not available. None of these patients had a history of diabetes mellitus. $* \mathrm{HCC}$ recurred 2.5 years after initiation of sofosbuvir/ribavirin. ${ }^{*} \mathrm{HCC}$ occurred 1.5 years, and 2.5 years after the initiation of sofosbuvir/ribavirin.

Table VI. Clinical characteristics of the patients who underwent a follow-up examination at least 1 year after the end of treatment.

\begin{tabular}{|c|c|c|c|c|}
\hline \multirow[b]{2}{*}{ Characteristic } & \multicolumn{4}{|c|}{ HCC occurrence } \\
\hline & Total patients $(\mathrm{n}=77)$ & Patients without $(n=75)$ & Patients with $(n=2)$ & $p$-Value* \\
\hline Male/female, $\mathrm{n}$ & $35 / 42$ & $33 / 42$ & $2 / 0$ & 0.116 \\
\hline Mean age $\pm \mathrm{SD}$, years & $60.9 \pm 11.1$ & $60.8 \pm 11.2$ & $64.5 \pm 0.7$ & 0.646 \\
\hline Mean $\mathrm{BMI} \pm \mathrm{SD}, \mathrm{kg} / \mathrm{m}^{2}$ & $23.3 \pm 3.9$ & $23.3 \pm 3.9$ & $22.5 \pm 3.1$ & 0.774 \\
\hline Mean $H C V$ RNA $\pm \mathrm{SD}, \mathrm{IU} / \mathrm{ml}$ & $2,175,000 \pm 2,995,000$ & $2,162,000 \pm 3,009,000$ & $2,664,000 \pm 3,320,000$ & 0.816 \\
\hline Genotype: $2 \mathrm{a} / 2 \mathrm{~b} /$ unknown, $\mathrm{n}$ & $47 / 29 / 1$ & $46 / 28 / 1$ & $1 / 1 / 0$ & 0.745 \\
\hline Interferon naïve/experienced, $\mathrm{n}$ & $70 / 7$ & $69 / 6$ & $1 / 1$ & 0.650 \\
\hline Chronic hepatitis/cirrhosis, $\mathrm{n}$ & $62 / 15$ & $61 / 14$ & $1 / 1$ & 0.269 \\
\hline Mean AST $\pm S D, I U / 1$ & $50.4 \pm 38.0$ & $50.4 \pm 38.5$ & $59.5 \pm 0.7$ & 0.973 \\
\hline Mean ALT $\pm S D$, IU/1 & $54.9 \pm 52.7$ & $55.0 \pm 33.4$ & $51.0 \pm 21.2$ & 0.916 \\
\hline Mean hemoglobin \pm SD, g/dl & $13.5 \pm 1.6$ & $13.5 \pm 1.5$ & $13.3 \pm 2.8$ & 0.855 \\
\hline Mean platelet count \pm SD, $10^{3} / \mu 1$ & $183 \pm 68$ & $183 \pm 68$ & $180 \pm 38$ & 0.0618 \\
\hline Mean $\mathrm{eGFR} \pm \mathrm{SD}, \mathrm{ml} / \mathrm{min} / 1.73 \mathrm{~m}^{2}$ & $76.8 \pm 16.0$ & $76.7 \pm 16.2$ & $77.9 \pm 1.5$ & 0.917 \\
\hline History of HCC: Yes/no, n & $75 / 2$ & $74 / 1$ & $1 / 1$ & $<0.00001$ \\
\hline History of diabetes mellitus: Yes/no, $\mathrm{n}$ & $60 / 17$ & $59 / 16$ & $1 / 1$ & 0.334 \\
\hline Follow-up period (years) & $2.7 \pm 0.8$ & $2.7 \pm 0.7$ & $3.5 \pm 0.7$ & 0.182 \\
\hline
\end{tabular}

BMI: Body mass index; AST: aspartate aminotransferase; ALT: alanine aminotransferase; eGFR: estimated glomerular filtration rate.*By Student's $t$-test or chi-square test.

The 12-week combination therapy with sofosbuvir/ ribavirin led to higher SVR rates, with better adherence and fewer adverse effects. Late relapse was infrequent. The limitation of the present study is that the number of study patients may have been too small. In conclusion, continued follow-up will be needed to determine whether unexpected events occur in $H C V$ GT2-infected patients who achieve SVR after treatment with sofosbuvir/ribavirin. However, patients who achieve SVR should be carefully followed-up to allow screening for the development of HCC.

\section{Conflicts of Interest}

There are no conflicts of interest that could be perceived as prejudicing the impartiality of the research reported.

\section{Authors' Contributions}

Conception and design: Tomohiro Kaneko, Tatsuo Kanda, Mitsuhiko Moriyama; Collection and assembly of data: Tomohiro
Kaneko, Tatsuo Kanda, Kazushige Nirei; Data analysis and interpretation: Tomohiro Kaneko, Tatsuo Kanda, Mitsuhiko Moriyama; All Authors; Article writing: Tomohiro Kaneko, Tatsuo Kanda, Mitsuhiko Moriyama; Final approval of article: All Authors.

\section{Acknowledgements}

The Authors thank all staff members for their care at Nihon University School of Medicine Itabashi Hospital. This work was supported by the JSPS KAKENHI (GRANT Number JP17K09404) and the Nihon University Academic Research Grant (Sogo Kenkyu 15-009).

\section{References}

1 Bertuccio P, Turati F, Carioli G, Rodriguez T, La Vecchia C, Malvezzi $M$ and Negri E: Global trends and predictions in hepatocellular carcinoma mortality. J Hepatol 67(2): 302-309, 2017. PMID: 28336466. DOI: 10.1016/j.jhep.2017.03.011

2 Di Bisceglie AM: Hepatitis C and hepatocellular carcinoma. Hepatology 26(3 Suppl 1): 34S-38S, 1997. PMID: 9305661. 
3 Omata M, Nishiguchi S, Ueno Y, Mochizuki H, Izumi N, Ikeda F, Toyoda H, Yokosuka O, Nirei K, Genda T, Umemura T, Takehara T, Sakamoto N, Nishigaki Y, Nakane K, Toda N, Ide T, Yanase M, Hino K, Gao B, Garrison KL, Dvory-Sobol H, Ishizaki A, Omote M, Brainard D, Knox S, Symonds WT, McHutchison JG, Yatsuhashi $\mathrm{H}$ and Mizokami M: Sofosbuvir plus ribavirin in Japanese patients with chronic genotype $2 \mathrm{HCV}$ infection: An open-label, phase 3 trial. J Viral Hepat 21(11): 762768, 2014. PMID: 25196837. DOI: 10.1111/jvh.12312

4 Omata M, Kanda T, Yokosuka O, Crawford D, Al-Mahtab M, Wei L, Ibrahim A, Lau GK, Sharma BC, Hamid SS, Chuang WL and Dokmeci AK: Features of hepatitis $\mathrm{C}$ virus infection, current therapies and ongoing clinical trials in ten Asian Pacific countries. Hepatol Int 9(4): 486-507, 2015. PMID: 25941137. DOI: $10.1007 / \mathrm{s} 12072-015-9630-4$

5 Kanda T, Nakamura M, Yasui S, Haga Y, Tawada A, Suzuki E, Ooka Y, Takahashi K, Sasaki R, Wu S, Nakamoto S, Arai M, Imazeki $\mathrm{F}$ and Yokosuka O: Treatment of Real-world $\mathrm{HCV}$ genotype 2-infected Japanese patients with sofosbuvir plus ribavirin. Biology 6(2): pii: E30, 2017. PMID: 28486403. DOI: 10.3390/biology6020030

6 Ogawa E, Furusyo N, Nomura H, Takahashi K, Higashi N, Kawano A, Dohmen K, Satoh T, Azuma K, Nakamuta M, Koyanagi T, Kato M, Shimoda S, Kajiwara E, Hayashi J and Kyushu University Liver Disease Study (KULDS) Group: Effectiveness and safety of sofosbuvir plus ribavirin for HCV genotype 2 patients 65 and over with or without cirrhosis. Antiviral Res 136: 37-44, 2016. PMID: 27789224. DOI: 10.1016/j.antiviral.2016.10.012

7 Watanabe T, Tokumoto Y, Joko K, Michitaka K, Horiike N, Tanaka Y, Tada F, Kisaka Y, Nakanishi S, Nonaka T, Yamauchi $\mathrm{K}$, Hirooka M, Abe M and Hiasa Y: Predictors of treatment efficacy and ALT non-normalization with sofosbuvir/ribavirin therapy for patients with hepatitis C virus genotype 2. J Med Virol 89(9): 1567-1573, 2017. PMID: 28165154. DOI: 10.1002/ jmv.24776

8 Mizokami M, Yokosuka O, Takehara T, Sakamoto N, Korenaga M, Mochizuki H, Nakane K, Enomoto H, Ikeda F, Yanase M, Toyoda H, Genda T, Umemura T, Yatsuhashi H, Ide T, Toda N, Nirei K, Ueno Y, Nishigaki Y, Betular J, Gao B, Ishizaki A, Omote M, Mo H, Garrison K, Pang PS, Knox SJ, Symonds WT, McHutchison JG, Izumi $\mathrm{N}$ and Omata $\mathrm{M}$ : Ledipasvir and sofosbuvir fixed-dose combination with and without ribavirin for 12 weeks in treatment-naive and previously treated Japanese patients with genotype 1 hepatitis C: An open-label, randomised, phase 3 trial. Lancet Infect Dis 15(6): 645-653, 2015. PMID: 25863559. DOI: 10.1016/S1473-3099(15)70099-X

9 Asahina Y, Itoh Y, Ueno Y, Matsuzaki Y, Takikawa Y, Yatsuhashi H, Genda T, Ikeda F, Matsuda T, Dvory-Sobol H, Jiang D, Massetto B, Osinusi AO, Brainard DM, McHutchison JG, Kawada $\mathrm{N}$ and Enomoto N: Ledipasvir-sofosbuvir for treating Japanese patients with chronic hepatitis C virus genotype 2 infection. Liver Int 38(9): 1552-1561, 2018. PMID: 29297980. DOI: $10.1111 /$ liv.13685

10 Naganuma A, Chayama K, Notsumata K, Gane E, Foster GR, Wyles D, Kwo P, Crown E, Bhagat A, Mensa FJ, Otani T, Larsen L, Burroughs $\mathrm{M}$ and Kumada $\mathrm{H}$ : Integrated analysis of 8-week glecaprevir/pibrentasvir in Japanese and overseas patients without cirrhosis and with hepatitis $\mathrm{C}$ virus genotype 1 or 2 infection. J Gastroenterol, 2019. PMID: 30868245. DOI: 10.1007/s00535-019-01569-7
11 Sasaki R, Meyer K, Moriyama M, Kato N, Yokosuka O, Ray RB, Aurora R, Ray R, and Kanda T: Rapid hepatitis C virus clearance by antivirals correlates with immune status of infected patients. J Med Virol 91(3): 411-418, 2019. PMID: 30192392. DOI: $10.1002 / j m v .25310$

12 Reig M, Mariño Z, Perelló C, Iñarrairaegui M, Ribeiro A, Lens S, Díaz A, Vilana R, Darnell A, Varela M, Sangro B, Calleja JL, Forns $\mathrm{X}$ and Bruix $\mathrm{J}$ : Unexpected high rate of early tumor recurrence in patients with $\mathrm{HCV}$-related HCC undergoing interferon-free therapy. J Hepatol 65(4): 719-726, 2016. PMID: 27084592. DOI: $10.1016 /$ j.jhep.2016.04.008

13 Conti F, Buonfiglioli F, Scuteri A, Crespi C, Bolondi L, Caraceni P, Foschi FG, Lenzi M, Mazzella G, Verucchi G, Andreone P and Brillanti S: Early occurrence and recurrence of hepatocellular carcinoma in HCV-related cirrhosis treated with direct-acting antivirals. J Hepatol 65(4): 727-733, 2016. PMID: 27349488. DOI: $10.1016 /$ j.jhep.2016.06.015

14 Singal AG, Rich NE, Mehta N, Branch A, Pillai A, Hoteit M, Volk M, Odewole M, Scaglione S, Guy J, Said A, Feld JJ, John BV, Frenette C, Mantry P, Rangnekar AS, Oloruntoba O, Leise M, Jou JH, Bhamidimarri KR, Kulik L, Tran T, Samant H, Dhanasekaran R, Duarte-Rojo A, Salgia R, Eswaran S, Jalal P, Flores A, Satapathy SK, Wong R, Huang A, Misra S, Schwartz M, Mitrani R, Nakka S, Noureddine W, Ho C, Konjeti VR, Dao A, Nelson K, Delarosa K, Rahim U, Mavuram M, Xie JJ, Murphy CC and Parikh ND: Direct- acting antiviral therapy not associated with recurrence of hepatocellular carcinoma in a multicenter North American Cohort Study. Gastroenterology 156(6): 1683-1692.e1, 2019. PMID: 30660729. DOI: 10.1053/ j.gastro.2019.01.027

15 Sarrazin C, Isakov V, Svarovskaia ES, Hedskog C, Martin R, Chodavarapu K, Brainard DM, Miller MD, Mo H, Molina JM and Sulkowski MS: Late relapse versus hepatitis C virus reinfection in patients with sustained virologic response after sofosbuvir-based therapies. Clin Infect Dis 64(1): 44-52, 2017. PMID: 27737953. DOI: 10.1093/cid/ciw676

16 Hayashi K, Ishigami M, Ishizu Y, Kuzuya T, Honda T, Hirooka Y, Toyoda H, Kumada T, Hattori M, Katano Y and Goto H: Late relapse of hepatitis $\mathrm{C}$ virus in patients with sustained virological response after daclatasvir and asunaprevir therapy. J Viral Hepat 25(12): 1446-1451, 2018. PMID: 29993164. DOI: 10.1111/ jvh.12967

17 National Cancer Institute: Common Terminology Criteria for Adverse Events (CTCAE) v5.0. Available from: https://ctep. cancer.gov/protocolDevelopment/electronic_applications/ctc.htm \#ctc_50 Last accessed on 2019/6/4.

18 Ohno O, Mizokami M, Wu RR, Saleh MG, Ohba K, Orito E, Mukaide M, Williams R and Lau JY: New hepatitis C virus $(\mathrm{HCV})$ genotyping system that allows for identification of $\mathrm{HCV}$ genotypes 1a, 1b, 2a, 2b, 3a, 3b, 4, 5a, and 6a. J Clin Microbiol 35(1): 201-207, 1997. PMID: 8968908.

19 European Association for the Study of the Liver: EASL Recommendations on Treatment of Hepatitis C 2018. J Hepatol 69(2): 461-511, 2018. PMID: 29650333. DOI: 10.1016/j.jhep. 2018.03.026

20 Kolykhalov AA, Agapov EV, Blight KJ, Mihalik K, Feinstone SM and Rice CM: Transmission of hepatitis $\mathrm{C}$ by intrahepatic inoculation with transcribed RNA. Science 277(5325): 570-574, 1997. PMID: 9228008. DOI: 10.1126/science.277.5325.570

21 Lohmann V, Körner F, Koch J, Herian U, Theilmann L and Bartenschlager R: Replication of subgenomic hepatitis $\mathrm{C}$ virus 
RNAs in a hepatoma cell line. Science 285(5424): 110-113, 1999. PMID: 10390360. DOI: 10.1126/science.285.5424.110

22 Kato T, Furusaka A, Miyamoto M, Date T, Yasui K, Hiramoto J, Nagayama K, Tanaka T and Wakita T: Sequence analysis of hepatitis $\mathrm{C}$ virus isolated from a fulminant hepatitis patient. J Med Virol 64(3): 334-339, 2001. PMID: 11424123.

23 Okamoto H, Kurai K, Okada S, Yamamoto K, Lizuka H, Tanaka T, Fukuda S, Tsuda F and Mishiro S: Full-length sequence of a hepatitis $\mathrm{C}$ virus genome having poor homology to reported isolates: Comparative study of four distinct genotypes. Virology 188(1): 331-341, 1992. PMID: 1314459.

24 Suzuki F, Suzuki Y, Sezaki H, Akuta N, Seko Y, Kawamura Y, Hosaka T, Kobayashi M, Saito S, Arase Y, Ikeda K, Mineta R, Watahiki S, Kobayashi M, Nakayasu Y, Tsuda H, Aoki K, Yamada I and Kumada H: Exploratory study on telaprevir given every $8 \mathrm{~h}$ at $500 \mathrm{mg}$ or $750 \mathrm{mg}$ with peginterferon-alpha- $2 \mathrm{~b}$ and ribavirin in hepatitis $C$ patients. Hepatol Res 43(7): 691-701, 2013. PMID: 23190247. DOI: 10.1111/hepr.12009

25 Bartlett SR, Grebely J, Eltahla AA, Reeves JD, Howe AYM, Miller V, Ceccherini-Silberstein F, Bull RA, Douglas MW, Dore GJ, Harrington P, Lloyd AR, Jacka B, Matthews GV, Wang GP, Pawlotsky JM, Feld JJ, Schinkel J, Garcia F, Lennerstrand J and Applegate TL: Sequencing of hepatitis C virus for detection of resistance to direct-acting antiviral therapy: A systematic review. Hepatol Commun 1(5): 379-390, 2017. PMID: 29404466. DOI: 10.1002/hep4.1050

26 Saxena V, Koraishy FM, Sise ME, Lim JK, Schmidt M, Chung RT, Liapakis A, Nelson DR, Fried MW, Terrault NA and HCVTARGET: Safety and efficacy of sofosbuvir-containing regimens in hepatitis C-infected patients with impaired renal function. Liver Int 36(6): 807-816, 2016. PMID: 26923436. DOI: 10.1111/liv.13102

27 Pisaturo M, Minichini C, Starace M, Caroprese M, Macera M, Brancaccio G, De Pascalis S, Santonicola A, Galeota Lanza A, Zampino R, Cotticelli G, Sagnelli E, Gaeta GB and Coppola N: Hepatitis $\mathrm{C}$ late relapse in patients with directly acting antiviralrelated sustained virological response at week 12 . Liver Int 39(5): 844-853, 2019. PMID: 30554459. DOI: 10.1111/liv.14025
28 Chen J, Florian J, Carter W, Fleischer RD, Hammerstrom TS, Jadhav PR, Zeng W, Murray J and Birnkrant D: Earlier sustained virologic response end points for regulatory approval and dose selection of hepatitis C therapies. Gastroenterology 144(7): 1450-1455.e2, 2013. PMID: 23470616. DOI: 10.1053/j.gastro. 2013.02.039

29 Kanda T, Nakamoto S, Sasaki R, Nakamura M, Yasui S, Haga Y, Ogasawara S, Tawada A, Arai M, Mikami S, Imazeki F and Yokosuka O: Sustained virologic response at 24 weeks after the end of treatment is a better predictor for treatment outcome in real-world $\mathrm{HCV}$-infected patients treated by $\mathrm{HCV}$ NS3/4A protease inhibitors with peginterferon plus ribavirin. Int J Med Sci 13(4): 310-315, 2016. PMID: 27076789. DOI: 10.7150/ ijms. 14953

30 Carrat F, Fontaine H, Dorival C, Simony M, Diallo A, Hezode C, De Ledinghen V, Larrey D, Haour G, Bronowicki JP, Zoulim F, Asselah T, Marcellin P, Thabut D, Leroy V, Tran A, Habersetzer F, Samuel D, Guyader D, Chazouilleres O, Mathurin P, Metivier S, Alric L, Riachi G, Gournay J, Abergel A, Cales P, Ganne N, Loustaud-Ratti V, D'Alteroche L, Causse X, Geist C, Minello A, Rosa I, Gelu-Simeon M, Portal I, Raffi F, Bourliere M, Pol S and French ANRS CO22 Hepather cohort: Clinical outcomes in patients with chronic hepatitis $\mathrm{C}$ after direct-acting antiviral treatment: a prospective cohort study. Lancet 393(10179): 1453-1464, 2019. PMID: 30765123. DOI: 10.1016/ S0140-6736(18)32111-1 